\title{
Upaya Pemenuhan Kebutuhan Seksual Warga Binaan Pemasyarakatan Guna Mencegah Penyimpangan Seksual di Dalam Lembaga Pemasyarakatan Sesuai Dengan Standard Minimum Rules
}

\author{
Yurike Violina \\ Politeknik Ilmu Pemasyarakatan \\ Jl. Raya Gandul No. 4, Cinere, Kota Depok, 16512 Telp/HP 082114777341 \\ Correspondence email: yurike.violina@gmail.com
}

\begin{abstract}
Abstrak. Kebutuhan seksual narapidana menjadi salah satu masalah yang ada di Lembaga Pemasyarakatan karena belum adanya regulasi yang jelas mengakibatkan kegelisahan narapidana sehingga menimbulkan banyaknya penyimpangan seksual terjadi di dalam Lembaga Pemasyarakatan. Kebutuhan biologi narapidana seharusnya dipenuhi oleh Negara karena juga tercantum di dalam instrument internasional Standard Minimum Rules For The Treatment Of Prisoners. Pemenuhan hak narapidana sudah diatur dalam Undang - Undang No. 12 Tahun 1995 Tentang Pemasyarakatan yang mana narapidana hanya kehilangan kebebasannya tetapi tidak kehilangan hak dan martabatnya sebagai manusia.
\end{abstract}

Kata Kunci: kebutuhan seksual, SMR, narapidana, penyimpangan seksual

Abstract. The sexual needs of prisoners become one of the problems in Penitentiary because there are no clear rules that cause prisoners anxiety so that there are many sexual deviations that occur in the Penitentiary. The biological needs of prisoners must be met by the State because they are also included in international instruments Standard Minimum Rules for the Treatment of Prisoners. The fulfilment of prisoners rights is regulated in Law No. 12 of 1995 concerning Penitentiary where detainees only lose their freedom but do not lose their rights and dignity as human beings.

Keyword: sexual needs, SMR, prisoners, sexual deviations

\section{PENDAHULUAN}

Sebagai makhluk sosial yang mempunyai berbagai macam kebutuhan di dalam menjalani alur kehipudannya, ada banyak tingkah laku manusia yang bisa diterangkan dengan melihat tendensi sebagai cara untuk mencapai tujuantujuan pribadi yang membuat kehidupan seseorang penuh dengan makna dan tentunya akan memuaskan. Tentunya narapidana sebagai terpidana yang menjalani masa pidana mengalami derita yang salah satunya adalah kehilangan kemerdekaan bergerak di Lembaga Pemasyarakatan tidak dapat memenuhi kebutuhan fisiologisnya dengan sendirian apalagi yang berkaitan dengan kebutuhan seksusal.

Menurut Maslow dalam mencapai kepuasan, seseorang harus berjenjang, tidak peduli seberapa tinggi jenjang yang sudah dilewati, kalau jenjang dibawah mengalami ketidakpuasan atau tingkat kepuasannya masih sangat kecil, dia akan kembali ke jenjang yang tak terpuaskan itu sampai memperoleh tingkat kepuasan yang dikehendaki. 5 kebutuhan dasar menurut Maslow yaitu:

1. Kebutuhan Fisiologis

Umumnya kebutuhan fisiologis bersifat neostatik (usaha menjaga keseimbangan unsur-unsur fisik) seperti makan, minum, gula, garam, protein, serta kebutuhan istirahat dan seks. Kebutuhan fisiologis ini sangat kuat, dalam keadaan absolut (kelaparan dan kehausan) semua kebutuhan lain ditinggalkan dan orang mencurahkan semua kemampuannya untuk memenuhi kebutuhan ini.

2. Kebutuhan Keamanan (Safety)

Sesudah kebutuhan fisiologis terpuaskan secukupnya, muncul kebutuhan keamanan, stabilitas, proteksi, struktur hukum, keteraturan, batas, kebebasan dari rasa takut dan cemas. Kebutuhan fisiologis dan keamanan pada dasarnya adalah kebutuhan mempertahankan kehidupan. Kebutuhan fisiologis adalah pertahanan hidup jangka pendek, sedang keamanan adalah pertahanan hidup jangka panjang.

3. Kebutuhan Dimiliki dan Cinta (Belonging and love)

Sesudah kebutuhan fisiologis dari keamanan relatif terpuaskan, kebutuhan dimiliki atau menjadi bagian dari kelompok sosial dan cinta menjadi tujuan yang dominan. Orang sangat peka dengan kesendirian, pengasingan, ditolak lingkungan, dan kehilangan sahabat atau kehilangan cinta. Kebutuhan dimiliki ini terus penting sepanjang hidup. Ada dua jenis cinta (dewasa) yakni Deficiency atau D-Love dan Being atau B-love

4. Kebutuhan Harga Diri

Saat kebutuhan dimiliki dan mencintai telah relatif terpuaskan, kekuatan untuk memotivasi melemah, diganti dengan motivasi harga diri. Adapun jenis harga diri yaitu yang pertama menghargai diri sendiri (self respect) dan yang kedua mendapat penghargaan dari orang lain (respect from another). 
Yurike Violina, Upaya Pemenuhan Kebutuhan Seksual Warga Binaan Pemasyarakatan Guna Mencegah Penyimpangan Seksual di Dalam Lembaga Pemasyarakatan Sesuai Dengan Standard Minimum Rules

\section{Kebutuhan Aktualisasi Diri}

Lahirnya kebutuhan meta atau kebutuhan aktualisasi diri adalah sesudah keseluruhan kebutuhan dasar terpenuhi. Kebutuhan meta menjadi sesuatu yang orang-orang wujudkan semaksimal mungkin dengan menuangkan seluruh bakat, kemampuan dan potensinya. Yang dimaksud dengan aktualisasi diri yaitu keinginan untuk mendapatkan kepuasan dengan dirinya sendiri (Self fullfilment), untuk menyadari semua potensi dirinya, untuk menjadi apa saja yang dia dapat melakukannya, dan untuk menjadi kreatif dan bebas mencapai puncak prestasi potensinya. Manusia yang dikatakan dapat mencapai target aktualisasi diri adalah manusia yang yang mendapatkan kepuasaannya dari kebutuhan-kebutuhan orang-orang di sekitarnya dan orang-orang itu tidak menyadari bahwa ada sesuatu hal yang menjadi kebutuhan orang lain.

Begitu juga dengan narapidana sebagai manusia memiliki kedudukan yang sama untuk tetap menikmati hak-hak dasarnya. Pemenuhan hak-hak tersebut telah dinyatakan dalam Undang-undang No. 12 Tahun 1995 tentang Sistem Pemasyarakatan yang sebelumnya dikukuhkan secara internasional tentang ketentuan minimum dalam pembinaan para tahanan yang dituangkan melalui Standard Minimum Rules for the Treatment of Prisoners. Ada 95 pasal yang dijadikan sebagai ketentuan dari negara-negara anggota dalam memperlakukan tahanan, tak terkecuali di negara kita negara Indonesia yang telah menjadi salah satu anggota PBB.

Dalam Pasal 10 Konvenan Internasional Hak-Hak Sipil dan Politik digariskan bahwa "Setiap orang yang dirampas kebebasannya wajib diperlakukan secara manusiawi dan dengan menghormati martabat yang melekat pada diri manusia"1. Berangkat dari pemahaman hak tersebut, maka kebutuhan biologis, sebagai bentuk turunan dari hak atas masalah pribadi dan keluarga, dan hak atas perlakuan manusiawi, pada prinsipnya dapat dikurangi atau dibatasi oleh negara. Dalam konteks individu yang sedang menjalani masa hukumannya di lembaga pemasyarakatan, tentu saja diperlukan sebuah derajat proporsionalitas terhadap pembatasan tersebut. Adapun prinsip proporsionalitas dalam hal ini ialah pertimbangan antara perlindungan hak individu di satu sisi dan ketertiban publik di sisi lain. ${ }^{2}$

Kebutuhan seksual terhadap Warga Binaan Pemasyarakatan adalah hal yang wajib untuk dipenuhi dan ini adalah hak dasar sebagai manusia apalagi jika narapidana tersebut dulunya aktif dalam hubungan sex maka keinginanya untuk memenuhi hasratnya lebih kuat. Akan tetapi karena adanya keterbatasan di dalam lembaga pemasyarakatan yang akhirnya mengakibatkan sejumlah narapidana yang tidak kuat menahan hasratnya melakukan masturbasi, bahkan bisa melakukan penyimpangan seksual seperti sodomi atau berhubungan sesama jenis karena gairah seksual mereka yang tidak dapat mereka salurkan sebagaimana mestinya.

Penyimpangan yang terjadi di dalam penjara memiliki berbagai macam bentuk, dianataranya yaitu penyimpangan seksual, di mana penyaluran hasrat seksual disublimasikan dengan berbagai cara, yang dikenal dengan "homobo'loalabui"" (homoseksual), "ana-anakan" (karakter istri), "bapak- bapakan" (karakter suami), "pelacur" (homo), "eentogan/wartil" (hubungan di Lapas tanpa izin), "memerian” (hubungan seksual di luar Lapas tanpa izin) 4

Hubungan homosexual sudah lazim ada di lembaga pemasyarakatan. Banyak narapidana yang menajadi korban pemuas hasrat seksual para narapidana yang lebih berkuasa diantara kalangannya. Kebanyakan yang menjadi korban adalah narapidana yang umurnya masih muda memiliki kulit yang halus, putih dan termasuk golongan anak hilang.

Penyimpangan seksual sangat berbahaya karena dikhawatirkan akan menjadi kebiasaan yang dibawa narapidana setelah keluar dari lemabaga pemasyaraktan. Bahkan kebiasaan ini berbahaya bagi kesehatan karena sodomi atau anal sex ini adalah salah satu faktor penyebab penularan virus HIV/AIDS.

\section{METODE}

Jenis penelitian ini menggunakan metode penelitian kualitatif dengan pendekatan yuridis empiris (hukum sebagai kenyataan sosial, kultural atau das sein). Instrumen pengumpulan data menggunakan data sekunder melalui studi kepustakaan dan wawancara. Yang dimaksud dengan penelitian kepustakaan (library research) yaitu penelitian yang bersifat teoritis yang diperoleh lewat modul, diktat-diktat, buku-buku, dokumen-dokumen perundang-undangan,

${ }^{1}$ Kovenan Internasional Hak-Hak Sipil dan Politik yang diratifikasi oleh Negara Indonesia melalui Undang-Undang Nomor 12 Tahun 2005 tentang Pengesahan Internatonal Covenant on Civil and Political Rights.

${ }^{2}$ Harison Citrawan. "Seksualitas Dalam Penjara: Studi Tentang Kebutuhan Biologis Narapidana dari Prespektif Hak Asasi Manusia”, dalam Jurnal Widyariset,, Vol. 16, No. , April 2013: 31-38

${ }^{3}$ Perilaku homoseksual dikenal sebagai homo-boolabui (bool berarti anus dalam Bahasa sunda). Biasanya pembool adalah seorang narapidana atau yang dianggap sebagai kepala kamarnya, sedangkan yang menjadi sasarannya adalah penghuni yang berkulit putih, berwajah imut -imut dan suara kentutnya masih nyaring. Dikutip dari Tesis Pengelolaan Pemenuhan Kebutuhan Biologis (seksual) Narapidana di Lapas Bekasi oleh Sri Pamudji, (Jakarta: Universitas Indonesia Program Pascasarjana, 2005), hal. 3-4.

${ }^{4}$ A. Josias Simon R dan Thomas Sunaryo, Stud Kebudayaan Lembaga Pemasyarkatan di Indonesia, (Bandung: CV Lubuk Agung, 2011), hal. 12. 
Yurike Violina, Upaya Pemenuhan Kebutuhan Seksual Warga Binaan Pemasyarakatan Guna Mencegah Penyimpangan Seksual di Dalam Lembaga Pemasyarakatan Sesuai Dengan Standard Minimum Rules

hasil-hasil penelitian, serta internet dan data-data yang diperoleh relevan dan berkaitan dengan penelitian yang dilakukan.

Setelah pengumpulan data dilakukan, maka data tersebut dianalisis secara kualitatif dengan melakukan pengamatan dan menghubungkan data-data yang sudah diperoleh dengan ketentuan-ketentuan yang terkait dengan masalah yang diteliti.

\section{HASIL DAN PEMBAHASAN}

Standard Minimum Rules For The Treatment Of Prisoners adalah penerapan aturan standard tentang penanganan tahanan yang diadopsi dari kongres Perserikatan Bangsa-Bangsa tentang pencegahan kejahatan dan tindak pelaku kejahatan, yang diadakan di Jenewa pada Tahun 1955, dan disetujui oleh Dewan Ekonomi dan Sosial melalui Resolusi 663 C (XXIV) tertanggal 31 Juli 1957 dan Resolusi 2076 (LXII) tertanggal 13 Mei 1977 dan aturan ini berlaku secara Internasional. $^{5}$

Indonesia yang mengakui instrumen Internasional The Standard Minimum Rules For The Treatment Of Prisoners selanjutnya disingkat SMR tahun 1957 mengatur hak-hak narapidana yang kemudian berbagai ketentuan dalam SMR tersebut diimplementasikan ke dalam Undang-Undang No. 12 Tahun 1995 tentang Pemasyarakatan, terkait hak-hak narapidana diatur dalam Pasal $14^{6}$.

Di dalam SMR mengatur pentingnya hubungan sosial bagi para narapidana padal Pasal 79, yang mengatakan bahwa seseorang narapidana perlu mendapat perhatian khusus dalam pemeliharaan dan peningkatan hubungan sevagaimana yang diinginkan dalam kepentingan terbaik dengan keluarganya. ${ }^{7}$

Dengan latar belakang sebagai narapidana maka pihak pemerintah telah mengatur alur pemenuhan kebutuhan dasar narapidana misalnya kebutuhan fisiologi seperti kebutuhan nutrsi yang harus terpenuhi, disamping hal itu kebutuhan yang lainnya seperti kebutuhan seksual juga harusnya dipenuhi. Karena pada dasarnya, kebutuhan seksual adalah kebutuhan dasar manusia yang seharusnya dipenuhi dan didapatkan oleh narapidana.

Beberapa pihak berprasangka bahwasannya kegagalan pemerintah dalam menangani permasalahan ini yang menimbulkan banyaknya penyimpangan seksual di dalam Lembaga Pemasyarakatan. Berdasarkan penelitian yang dilakukan banyak ragam penyimpangan seksual narapidana berdasarkan objek dan cara memperoleh objek.

Banyak hal yang dapat dilakukan untuk pemenuhan kebutuhan seksual narapidana. Contohnya bisnin seks yang ada di dalam Lapas Cipinang jika memiliki uang mereka dapat menyewa PSK yang sudah disiapkan oleh petugas dan bisa menyewa ruangans esuai dengan kelas mereka. Ada kelas ekonomi, bisnis dan eksekutif teragntung isi kantong narapidana. Hal ini dilakukan untuk memenuhi kebutuhan hasrat mereka dan dianggap sebagai rahasia umum di Lapas tersebut. $^{8}$

Bagi narapidana yang tidak memiliki uang mereka biasa disebut sebagai anak hilang dikarenakan mereka tidak pernah sekalipun dibesuk oleh keluarga atau bahkan teman-temannya. Kondisi ini lah yang memaksa mereka untuk memuaskan gairah mereka dengan sesamanya narapidana. Lokasi berkencan mereka biasanya yaitu tiap-tiap sudut yang sepi yang ada di kawasan Lapas. Biasanya, narapidana yang umurnya relatif masih muda dijadikan sebagai korban pemuas, narapidana belia ini selalu menjadi sasaran narapidana-narapidana dewasa dan selalu dijadikan objek pemuas gairah seks mereka yang tidak tersalurkan.

Penyediaan conjugal visit dalam Lembaga Pemasyarakatan merupakan salah satu cara yang dapat di lakukan untuk mencegah terjadinya penyimpangan yang terjadi di dalam Lembaga Pemasyarakatan. Conjugal visit dapat membantu narapidana untuk memelihara dan meningkatkan hubungan dengan pasangan sahnya, sehingga dapat memenuhi kebutuhan hasrat seksual narapidana.

Melihat Undang-Undang Nomor 36 Tahun 2009 tentang kesehatan, dalam pasal 72 bagian a dikatakan bahwa setiap orang berhak mendapatkan kehidupan reproduksi dan seksual yang sehat, aman, tanpa peksaan dengan pasangan yang sah, dan selanjutnya diatur dalam Pasal 73, Pemerintah wajib untuk menyediakan sarana informasi dan pelayanan terkait akan hal tesebut. ${ }^{9}$

Maka dari itu untuk menjaga kesehatan narapidana dari penyakit akibat penyimpangan seksual, pemerintah harus menyediakan fasilitas yang layak berupa sarana untuk menyalurkan gairah seksualnya dengan pasangan sah mereka tentunya dengan cara yang baik dan benar. Penyakit seperti HIV/AIDS, gangguan reproduksi dan penyakit

5 John Kleinig, 'Standard Minimum Rules for the Treatment of Prisoners', Prisoners' Rights, 2018, 407-20 <https://doi.org/10.4324/9781315089461-18>.

${ }^{6}$ I Nengah Suantra Ni Nyoman Ome Tania Langden, 'TINJAUAN YURIDIS URGENSI KEBIJAKAN CONJUGAL VISIT SEBAGAI PEMENUHAN HAK BAGI NARAPIDANA’, 1-15.

${ }^{7}$ Kleinig.

8 A. Sulistyawan, 'Membangun Model Hukum Yang Memerhatikan Kebutuhan Seksual Narapidana Di Lembaga Pemasyarakatan : Telaah Paradigma Konstruktivisme', Jurnal Ilmu Hukum Riau, 4.1 (2014), 9094.

9 'UNDANG-UNDANG REPUBLIK INDONESIA NOMOR 36 TAHUN 2009 TENTANG KESEHATAN', $2009,31-47$. 
Yurike Violina, Upaya Pemenuhan Kebutuhan Seksual Warga Binaan Pemasyarakatan Guna Mencegah Penyimpangan Seksual di Dalam Lembaga Pemasyarakatan Sesuai Dengan Standard Minimum Rules

kelamin menular akan meningkat apabila pemerintah tidak memperhatikan masalah ini dan tidak mengatur pola perilaku seksual selama di dalam Lembaga Pemasyarakatan dengan benar.

Dalam Pasal 10 Konevenan hak-hak sipil dan politik menyatakan bahwa setiap orang yang dirampas kemerdekaannya, wajib untuk diperlakukan dengan cara manusiawi dengan mempertahankan harkat dan martabat yang melekat pada dirinya sebagai manusia. Dari pasal tersebut dapat disimpulkan bahwa kebutuhan biologis salah satu hak yang harus dipenuhi.

Akan tetapi derajat proposionalitas diperlukan untuk pembatasan dalam artian pertimbangan perlindungan hak individu dengan ketertiban publik. Fungsi Pemasyarakatan diperlukan sebagai dasar pemenuhan dengan mencakup prinsip- prinsip perlindungan hak asasi manusia.

Pemberian pidana hanya menghilangkan kemerdekaan seseorang, bukan merupakan tindakan balas dendam oleh negara, dalam artian tidak ada penyiksaan yang berupa ucapan, tindakan ataupun penempatan terpidana. ${ }^{10}$ Program conjugal visit sebagai salah satu tindakan memberikan perawatan yang tidak menyiksa.

Gairah seseorang untuk berhubungan seksual tidak dapat "dipenjarakan", dikatakan oleh Benjamin Karpman bahwa dorongan seksual merupakan hal yang sangat dasar dan naluriah dan tidak dapat terhenti oleh karena penahanan (kurungan penjara). Tahanan berusaha mengontrol sejak awal dipenjara untuk mempertahankan heteroseksualitasnya. Kunjungan dari anggota keluarga sering dapat meredakan ketengangan. ${ }^{11}$

Kebijakan yang mengatur mengenai masalah pemenuhan hak narapidana akan kebutuhan seksual selama ini belum jelas. Akibat ketidak jelasan kebijakan yang mengatur pemenuhan kebutuhan seksual narapidana banyak narapidana yang merasakan kegelisahan sehingga menimbulkan penyimpangan seksual sesama jenis.

Melihat fakta yang ada maka sudah seharusnya pemerintah lebih memperhatikan lagi bidang permasalah ini dikarenakan jika dilihat dari aspek psikologis merupakan kebutuhan yang wajib dipenuhi dan didapatkan oleh manusia yang sudah dewasa. Tidak adanya regulasi yang jelas akan kebutuhan tersebut mengindikasikan bahwa Negara mengabaikan dan mengingkari akan adanya kebutuhan dasar yang harus dipenuhi. Dibutuhkan kebijakan untuk memfasilitasi kebutuhan dan perilaku seksual narapidana.

Sudah banyak Negara lain yang juga memberikan fasilitas conjugal visit seperti Denmark, Belanda, wedia dan negara lainnya. Di Negara tersebut, conjugal visit diberikan dalam bentuk memberikan izin pada narapidana untuk dikunjungi pasangan selama tiga jam di ruangan yang sudah disediakan.

Permasalahan di dalam Lembaga Pemasyarakatan memang tidak hanya penyimpangan seksual masih ada overcrowded salah satunya yang menjadi prioritas Pemerintah tetapi bukan berarti Pemerintah dapat menutup mata akan hal ini karena dampak yang ditimbulkan akan menjadi permasalahan lain yang lebih rumit di dalam Lembaga Pemasyarakatan.

\section{SIMPULAN}

Pemenuhan kebutuhan biologi bagi narapidana adalah hal yang juga wajib untuk dipenuhi seperti layaknya kebutuhan makan dan minum. Kebutuhan ini juga merupakan hal yang harus diperhatikan agar terhindar dari penyimpangan seksual seperti yang marak terjadi di Lembaga Pemasyarakatan selama ini.

Berdasarkan hak-hak narapidana terkait kebutuhan seksual yang diakui dalam instrument internasional Standard Mminimum Rules For The Treatment Of Prisoners dan International Convenant On Ecomonic, Social and Cultural Right. Setiap orang walaupun direnggut kebebasannya tetapi pemenuhan atas kebutuhan wajib harus tetap dipenuhi.

Sebaiknya pemerintah memberikan fasilitas untuk mendukung kebijakan conjugal visit untuk tetap memenuhi kebutuhan biologis narapidana. Hal ini merupakan perilaku memanusiakan manusia dan penghapusan diskriminasi pada narapidana sesuai dengan tujuan pemasyarakatan.

\section{DAFTAR PUSTAKA}

A. Josias Simon R dan Thomas Sunaryo, Stud Kebudayaan Lembaga Pemasyarkatan di Indonesia, (Bandung: CV Lubuk Agung, 2011), hal. 12

Benjamin Karpman, Sex Life in Prison, Journal of Criminal Law and Criminology (1931-1951), Vol.38, No.5. (Januari-Februari 1948), h. 477

Gerson W. Bawengan., Pengantar Psikologi Kriminil, Jakarta,PT. Pradnya Paramita, 1991, h. 190.

Harison Citrawan. "Seksualitas Dalam Penjara: Studi Tentang Kebutuhan Biologis Narapidana dari Prespektif Hak Asasi Manusia”, dalam Jurnal Widyariset,, Vol. 16, No. , April 2013: 31-38

${ }^{10}$ Gerson W. Bawengan., Pengantar Psikologi Kriminil, Jakarta,PT Pradnya Paramita, 1991, h. 190.

${ }^{11}$ Benjamin Karpman, Sex Life in Prison, Journal of Criminal Law and Criminology (1931 -1951), Vol.38, No.5. (Januari-

Februari 1948), h. 477 
Yurike Violina, Upaya Pemenuhan Kebutuhan Seksual Warga Binaan Pemasyarakatan Guna Mencegah Penyimpangan Seksual di Dalam Lembaga Pemasyarakatan Sesuai Dengan Standard Minimum Rules

Kleinig, John, 'Standard Minimum Rules for the Treatment of Prisoners', Prisoners' Rights, 2018, 407-20 <https://doi.org/10.4324/9781315089461-18>

Kovenan Internasional Hak-Hak Sipil dan Politik yang diratifikasi oleh Negara Indonesia melalui Undang-Undang Nomor 12 Tahun 2005 tentang Pengesahan Internatonal Covenant on Civil and Political Rights.

Ni Nyoman Ome Tania Langden, I Nengah Suantra, 'TINJAUAN YURIDIS URGENSI KEBIJAKAN CONJUGAL VISIT SEBAGAI PEMENUHAN HAK BAGI NARAPIDANA', 1-15

Sulistyawan, A., 'Membangun Model Hukum Yang Memerhatikan Kebutuhan Seksual Narapidana Di Lembaga Pemasyarakatan : Telaah Paradigma Konstruktivisme', Jurnal Ilmu Hukum Riau, 4.1 (2014), 9094

'UNDANG-UNDANG REPUBLIK INDONESIA NOMOR 36 TAHUN 2009 TENTANG KESEHATAN', 2009, 3147 